\title{
Macro Level Changes in Livestock System of Tamil Nadu due to Climate Change
}

\author{
K. Oviya, V. Uma, N. Narmatha* and D. Anandha Prakash Singh \\ Department of Veterinary and Animal Husbandry Extension Education, Veterinary College \\ and Research Institute, Namakkal, India \\ *Corresponding author
}

\section{Keywords}

Climate change, system of rearing, grazing resources, livestock farmers, small farmers, marginal farmers

Article Info

Accepted: 12 March 2021 Available Online: 10 April 2021
Climate sensitive sectors such as agriculture and livestock are highly vulnerable to climate change than other systems. Livestock sector provides employment to 22.45 million, and also provides food, fuel, manure and draught power and is the stable source of income in the rainfed regions. Districts of Tamil Nadu classified into low, medium and high category based on livestock population and two median districts were selected. From selected districts taluks were selected and from each taluk 10 respondents were selected. Thus a total of 120 farmers constituted the respondents for study. Pre tested interview schedule was used to collect the information. Average age of the respondents was 55.43 years, with range of 47 to 80 years. $62.5 \%$ were male, $70.83 \%$ were in backward community and in nuclear family (60\%). Livestock rearing was the primary occupation for $72.5 \%$, average land holding was 4.5 acres which ranged from landless to 50 acres. Nearly half $(42.5 \%)$ were marginal farmers followed by small farmers (35.83\%). Cattle and goat population increased by $32.20 \%$ and $60 \%$ of the respondents increased; buffalo and sheep population decreased by $80 \%$ and $52.94 \%$. Extensive system of rearing was reduced and shifted to semi-intensive (42\% to $85.59 \%$ ) and very few followed intensive system of rearing (up to $6.78 \%$ ). Grazing at roadside/ ridges/ bunds and common property resources had increased to $35.83 \%$ and $32.5 \%$.

\section{Introduction}

Climate change is a global phenomenon which affects all livelihood sectors either directly or indirectly. Intergovernmental Panel on Climate Change (IPCC, 2014) defined climate change is any change in climate over a period of time which comes out as the result of both human and natural actions. Climate sensitive sectors such as agriculture and livestock are highly vulnerable than other systems. Climate change is already negatively affecting agriculture and allied sectors in the developing countries and it is likely to worsen (IPCC, 2007). Globally, livestock sector, among agricultural sub-sectors is growing faster by providing livelihood for about 1.3 billion with $40 \%$ of agricultural output (Steinfeld et al., 
2006). In India, livestock sector provides employment to 22.45 million people, and also provides food, fuel, manure and draught power and is the most stable source of income for people in the rainfed regions (Kumar et al., 2015).

Tamil Nadu is one of the water starved states in India. Depletion of natural resources coupled with degradation of land, alteration in water resources, poor productivity, low level of technology adoption, fodder scarcity are posing serious challenges to development and food security of Tamil Nadu. Hence it is necessary to assess the macro level changes in livestock system of Tamil Nadu.

\section{Materials and Methods}

An ex-post-facto research design was adopted in the study. The districts of Tamil Nadu were classified into low, medium and high category based on livestock population and from each category, two median districts were selected. From the six selected districts, taluks with low and high livestock population were selected for the study.

Livestock farmers with 30 years of livestock farming experience constituted the sample frame and 10 farmers from each selected taluks were selected. Thus a total of 120 farmers constituted the respondents for study. Pre tested interview schedule was used to collect the information.

\section{Results and Discussion}

The average age of the respondents was 55.43 years, which ranged from 47 to 80 years. It could be inferred from Table 1 that nearly two-third (63.33\%) of the overall respondents were in the age group of 47 to 58 years followed by 59 to 69 years (29.17\%) and more than 69 years $(7.5 \%)$. Three-fifth $(62.5 \%)$ of the respondents were male and the remaining
$37.5 \%$ were female. Majority of the respondents belonged to backward community $(70.83 \%)$ followed by schedule caste (15.83\%) and most backward community (13.33\%). None of the respondents were from forward community and schedule tribe.

Majority of the respondents (60\%) belonged to nuclear family and $40 \%$ of the respondents were in joint family in overall districts.

Family size of the respondents ranged from 1 to 8 members with an average family size of 4.1 members. Majority of the respondents (87.5\%) had up to five members in their family and the remaining $12.5 \%$ of the respondents had more than five members in their family.

About one-third (32.5\%) of the overall respondents were illiterate since the respondents are aged. Among the literate respondents, equal percentage ( $18.33 \%$ each) had primary and high school education followed by middle school education $(16.67 \%)$, collegiate $(8.33 \%)$ and higher secondary school education (5.83\%). Implementation of state educational policy might have improved the literacy per cent.

Livestock rearing was the primary occupation for $72.5 \%$ of the respondents followed by agriculture $(10.83 \%)$, agricultural labour $(9.17 \%)$ and non-farm sector $(7.5 \%)$. The average livestock farming experience of the respondents was 34.3 years with the range of 30 to 60 years.

The average land holding was 4.5 acres which ranged from landless to 50 acres. Nearly half $(42.5 \%)$ of the respondents were marginal farmers followed by small farmers (35.83\%), large farmers $(9.17 \%)$, medium farmers (8.33\%) and landless (4.17\%). Among all categories of farmers, small farmers and marginal farmers dominated. 
Table.1 Demographic profile of the respondents

\begin{tabular}{|c|c|c|}
\hline & & $(\mathrm{n}=120)$ \\
\hline S. No & Category & f $(\%)$ \\
\hline \multicolumn{3}{|c|}{ Age } \\
\hline 1. & 47 to 58 years & $76(63.33)$ \\
\hline 2. & 59 to 69 years & $35(29.17)$ \\
\hline 3. & Above 69 years & $9(7.5)$ \\
\hline \multicolumn{3}{|c|}{ Gender } \\
\hline 1. & Male & $75(62.5)$ \\
\hline 2. & Female & $45(37.5)$ \\
\hline \multicolumn{3}{|c|}{ Community } \\
\hline 1. & Forward community & $0(00)$ \\
\hline 2. & Backward community & $85(70.83)$ \\
\hline 3. & Most backward community & $16(13.33)$ \\
\hline 4. & Schedule caste & $19(15.83)$ \\
\hline 5. & Schedule tribe & $0(00)$ \\
\hline \multicolumn{3}{|c|}{ Family type } \\
\hline 1. & Joint & $48(40)$ \\
\hline 2. & Nuclear & $72(60)$ \\
\hline \multicolumn{3}{|c|}{ Family size } \\
\hline 1. & Up to 5 members & $105(87.5)$ \\
\hline 2. & More than 5 members & $15(12.5)$ \\
\hline \multicolumn{3}{|c|}{ Educational status } \\
\hline 1. & Illiterate & $39(32.5)$ \\
\hline 2. & Primary school & $22(18.33)$ \\
\hline 3. & Middle school & $20(16.67)$ \\
\hline 4. & High school & $22(18.33)$ \\
\hline 5. & Higher secondary school & $7(5.83)$ \\
\hline 6. & Collegiate & $10(8.33)$ \\
\hline \multicolumn{3}{|c|}{ Primary occupation } \\
\hline 1. & Livestock rearing & $87(72.5)$ \\
\hline 2. & Agriculture & $13(10.83)$ \\
\hline 3. & Agricultural labour & $11(9.17)$ \\
\hline 4. & Non-farm & $9(7.5)$ \\
\hline \multicolumn{3}{|c|}{ Secondary occupation } \\
\hline 1. & Livestock rearing & $29(24.17)$ \\
\hline 2. & Agriculture & $83(69.17)$ \\
\hline 3. & Agricultural labour & $5(4.17)$ \\
\hline 4. & Non-farm & $3(2.5)$ \\
\hline \multicolumn{3}{|c|}{ Experience in livestock farming } \\
\hline 1. & 30 to 40 years & $106(88.33)$ \\
\hline 2. & 41 to 50 years & $12(10)$ \\
\hline 3. & More than 50 years & $2(1.67)$ \\
\hline \multicolumn{3}{|c|}{ Land holding } \\
\hline 1. & Landless & $5(4.17)$ \\
\hline 2. & Marginal farmers & $51(42.5)$ \\
\hline 3. & Small farmers & $43(35.83)$ \\
\hline 4. & Medium farmers & $10(8.33)$ \\
\hline 5. & Large farmers & $11(9.17)$ \\
\hline
\end{tabular}


Table.2 Livestock possession

\begin{tabular}{|c|c|c|c|}
\hline S. No & Category & $\begin{array}{c}\text { Before 30 years } \\
\text { f(\%) }\end{array}$ & $\begin{array}{c}\text { At present f } \\
(\mathbf{\%})\end{array}$ \\
\hline $\mathbf{1}$ & Below average SLU & $86(71.67)$ & $83(69.17)$ \\
\hline $\mathbf{2}$ & Above average SLU & $34(28.33)$ & $37(30.83)$ \\
\hline
\end{tabular}

Table.3 Change in livestock possession

\begin{tabular}{|c|c|c|c|c|c|c|}
\hline \multirow{2}{*}{ Category } & \multicolumn{2}{|c|}{ Increased } & \multicolumn{2}{c|}{ Decreased } & \multicolumn{2}{c|}{ No change } \\
\cline { 2 - 7 } & f & $\%$ & f & $\%$ & f & $\%$ \\
\hline \multicolumn{7}{|c|}{ Overall districts } \\
\hline Cattle & 38 & 32.20 & 29 & 24.58 & 51 & 43.22 \\
\hline Buffalo & 5 & 20.00 & 20 & 80.00 & 0 & 00.00 \\
\hline Sheep & 8 & 47.06 & 9 & 52.94 & 0 & 00.00 \\
\hline Goat & 36 & 60.00 & 21 & 33.30 & 4 & 6.70 \\
\hline
\end{tabular}

Table.4 System of rearing

\begin{tabular}{|r|c|c|c|}
\hline S. No & System of rearing & $\begin{array}{c}\text { Before 30 years } \\
\text { Cattle }\end{array}$ & At present \\
\hline $\mathbf{1}$ & Extensive & $34(28.81)$ & $9(7.63)$ \\
\hline $\mathbf{2}$ & Semi- intensive & $84(71.19)$ & $101(85.59)$ \\
\hline $\mathbf{3}$ & Intensive & $0(00)$ & $8(6.78)$ \\
\hline \multicolumn{5}{|c|}{ Buffalo } \\
\hline $\mathbf{1}$ & Extensive & $17(77.27)$ & $4(36.36)$ \\
\hline $\mathbf{2}$ & Semi- intensive & $5(22.73)$ & $7(63.64)$ \\
\hline $\mathbf{3}$ & Intensive & $0(00)$ & $0(00)$ \\
\hline $\mathbf{1}$ & & Eheep & $4(36.36)$ \\
\hline $\mathbf{2}$ & Semi- intensive & $8(66.67)$ & $6(54.55)$ \\
\hline $\mathbf{3}$ & Intensive & $4(33.33)$ & $1(9.09)$ \\
\hline \multicolumn{5}{|}{} & $0(00)$ & $28(56)$ \\
\hline $\mathbf{2}$ & Extensive & Goat & $21(42)$ \\
\hline $\mathbf{3}$ & Intensive & $27(93.1)$ & $1(2)$ \\
\hline
\end{tabular}

Table.5 Source of grazing

\begin{tabular}{|c|c|c|c|}
\hline S. & Category & \multicolumn{2}{|c|}{ Overall } \\
\cline { 3 - 4 } No & & Before 30 years & At present \\
\hline 1. & Own land & $17(14.17)$ & $20(16.67)$ \\
\hline $\mathbf{2 .}$ & Common property resources & $33(27.50)$ & $39(32.5)$ \\
\hline 3. & Common property resources and own land & $7(5.83)$ & $6(5)$ \\
\hline $\mathbf{4 .}$ & Roadside/Ridges/Bunds & $32(26.67)$ & $43(35.83)$ \\
\hline $\mathbf{5 .}$ & Forest & $31(25.83)$ & $12(10)$ \\
\hline
\end{tabular}


It could be inferred from Table 2 that negligible change was noticed in livestock possession. But perusal of district wise result, considerable change was observed between before 30 years and at present.

It is evident from Table 3 that cattle population was increased by $32.20 \%$ of the respondents and $43.22 \%$ did not have any change in cattle population at present when compared to 30 years before. Whereas, $80 \%$ of the respondents decreased buffalo population; $52.94 \%$ and $47.06 \%$ decreased and increased sheep population over 30 years respectively. But $60 \%$ of the respondents increased goat population. The researcher also recorded that Jersey cross and Holstein Friesian cross, Kangayam (indigenous) and non-descriptive were the cattle breeds maintained by the respondents in the study area. The $20^{\text {th }}$ Quinquennial Livestock Census also supported that $81.15 \%$ of cattle are crossbred and $18.85 \%$ indigenous cattle in Tamil Nadu. Murrah cross was the common breed of buffalo in the study area. Recognised goats breeds Kanni Adu, Kodi Adu Salem Black were the goat breeds maintained. Nondescriptive and Mecheri were the sheep breed maintained.

Extensive system of rearing was practiced before 30 years by the respondents for all the species and in all districts with the range of 28.81 to $93.1 \%$ (Table 4). But at present, the extensive system of rearing was reduced and shifted to semi-intensive (42\% to $85.59 \%$ ) and very few followed intensive system of rearing (up to $6.78 \%$ ).

Majority of the respondents used common property resources $(27.5 \%)$ followed by roadside/ ridges/ bunds (26.67\%) and forest (25.83\%) for grazing before 30 years. But, at present, grazing at roadside/ ridges/ bunds had increased to $35.83 \%$; common property resources had increased to $32.5 \%$; and meager increase was noticed in grazing at own land $(16.67 \%)$. But grazing in the forest area was reduced from $25.83 \%$ to $10 \%$ over 30 years (Table 5). It is in line with findings of Kumar (2013) that common property resources, roadside and forest areas were the sources of grazing. It contradicts with the report of Sharma and Bhaduri (2007) stated that cent per cent of the farmers used common grazing land and own land.

Grazing lands were affected by drought and lower rainfall and it was directly affected by temperature and solar radiation; and indirectly by pasture growth (Nardone et al., 2010). The invasive plants were the major cause for decline in grazing land was also reported by Shashidahra and Reddy (2012).

It could be concluded from the results that alteration in livestock species was noticed over years. Drastic decrease of buffalo population might be due to increase in temperature causes heat stress, silent heat and other reproductive problems, lack of natural wallowing facility and decreased grazing land due to shortfall of rainfall with increased temperature might have influenced the buffalo population over the years. Goat is a climate resilient, hardy and highly adaptive to semiintensive system of rearing when compared to sheep, hence the respondents shifted to goat enterprise.

\section{References}

Inter Governmental Panel on Climate Change (IPCC). 2014. Climate Change (2007): Impacts, Adaptation and Vulnerability. Report of the Working Group II. Cambridge University Press, UK.

Kumar, S., B. M. K. Raju, C. A. Ramarao and T. Ramilan. 2015. Sensitivity of livestock production to climatic variability under Indian dry lands and future perspective. Current Agriculture 
Research Journal, 3(2): 142-149.

Kumar, V. 2013. Analysis of goat farming practices in southern agro-climatic zone of Tamil Nadu. Unpublished Ph.D. thesis, Tamil Nadu Veterinary and Animal Sciences University, Chennai.

Nardone, A., B. Ronchi, N. Lacetera, M.S. Raniera and U. Bernabucci. 2010. Effects of climate changes on animal production and sustainability of livestock systems. Livestock Science, 130: $57-60$.

Sharma, A. and A. Bhaduri. 2007. The "Tipping Point" in Indian agriculture:
Understanding the withdrawal of the Indian rural youth. Asian Journal of Agriculture and Development, 6(1):115-129.

Shashidahra, K. K. and B. S. Reddy. 2012. Farmers perceptions and adaptations about changing climate and its variability in UKP area of Karnataka. Indian Research Journal of Extension Education, 1: 196 - 201.

Steinfeld, H., P. Gerber, T. Wassenaar, V. Castel, M. Rosales, C. De Haan. 2006. Livestock's long shadow: Environmental issues and options. FAO, Rome, Italy.

\section{How to cite this article:}

Oviya, K., V. Uma, N. Narmatha and Anandha Prakash Singh, D. 2021. Macro Level Changes in Livestock System of Tamil Nadu due to Climate Change. Int.J.Curr.Microbiol.App.Sci. 10(04): 246-251. doi: https://doi.org/10.20546/ijcmas.2021.1004.024 